\title{
PERGULATAN FILOSOFIS TENTANG THEISME DAN ATHEISME
}

\author{
Oleh: \\ Sindung Tjahyadi \\ (Disampaikan dalam Sapere Aude '02, 6 September 2002)
}

\section{PENDAHULUAN}

Filsafat adalah sebuah kajian tentang semua dan seluruh kehidupan sebagaimana kita hidup di dalamnya, dan juga mengkaji semua pengalaman manusia (Washburn, 1997:3). Disiplin ilmu lain mungkin saja juga mempelajari kehidupan, namun tidak ada sebuah kajian yang menyeluruh sebagaimana yang dilakukan oleh filsafat. Filsafat tidak hanya mengkaji bagian saja, atau keseluruhan saja, namun mengkaji bagiandalam rangka keseluruhan, dan sebaliknya. Semua aspek kehidupan, sejauh itu berkaitan dengan persoalan eksistensi manusia, akan menjadi bagian dari kajian filsafat. Filsafat dapat mempersoalkan hal "sepele" seperti bangun, tidur, makan, menguap, kuliah, osp'r'ek, pacaran, kawin, dan lain sebagainya - namun filsafat mengkajinya secara "serius", dalam arti persoalan tersebut ditelaah sampai pada peneguhan premis terakhir atau premis utama, yang tidak tergantung pada peneguhan lain atau premis lain (Graybosch, 1998: 6). Dengan demikian tidak ada persoalan filsafat yang tidak penting. Namun dari berbagai persoalan filsafat, persoalan tentang "Ada - Tidak Ada Tuhan" merupakan persoalan paling penting (Washburn, 1997: 16). Pentingnya persoalan tersebut bukan pada "kesulitan teknis" yang ditimbulkan oleh "metode"-nya, melainkan pada konsekuensi dari jawaban apa pun yang diberikan atas pertanyaan "Apakah Tuhan ada?" Mengapa demikian?

Belajar filsafat tanpa pernah berfilsafat, sama seperti belajar estetika tanpa pernah mendengar musik, baca puisi, atau baca cerita pendek (Graybosch, 1998: 2). Sehingga belajar filsafat melibatkan seluruh "diri", akal, pikiran, perasaan, harapan, bahkan impian. Konsekuensinya, seseorang yang belajar filsafat meski siap untuk berubah, atau membongkar keyakinan "tradisional" yang selama ini telah dipegangnya. Keyakinan itu dapat berupa keyakinan tentang "tidur", "bangun", "makan", "kuliah", atau hal "sepele" lainnya, namun dapat pula yang meski berubah adalah keyakinan tentang "Tuhan". Sudah siapkah anda?

Beratnya belajar filsafat sesungguhnya terutama disebabkan oleh tuntutan untuk bersikap kritis, radikal dan rasional, dengan pilar utama: rasio. Mengapa pilar utamanya rasio? Karena bagaimana pun, berbeda dengan agama, filsafat merupakan bagian dari usaha rasional manusia untuk memahami realitas (Windt, 1982: 3). Bila tuntutan ini terlampau berat, ada jalan mudah untuk mengatasinya. Pertama: pindah bidang studi! Atau bila ini masih berat (karena terlanjur membayar SPP, BOP, atau yang lain), cara kedua mungkin dapat anda lakukan: menganggap 
tidak ada persoalan seserius yang dikaji oleh filsafat! Hidup ini yang ringan-ringan sajalah! Life is too short to worry! Pilihan kedua ini sah-sah saja, walau dengan resiko anda di "negeri asing", karena filsafat adalah "negeri orang bertanya!"

Terlepas dari beban dan resiko berbicara tentang Tuhan, saya akan membawa anda untuk mengenali sebagian wilayah kajian filsafat (wilayah paling angker!), yakni wilayah "ke-Tuhan-an", dan itu dapat dimulai dengan bertanya: Adakah Tuhan?

\section{Theisme dan Argumen-argumen Pokok}

Bidang kajian filsafat yang bergumul dengan masalah "ke-Tuhan-an" adalah Filsafat Agama dan Filsafat Ketuhanan (Teologi Metafisis). Filsafat Agama mendekati "Tuhan" melalui kajian filosofis tentang Agama, sedangkan Teologi Metafisis mendekati "Tuhan" melalui kajian "metafisis" tentang "Tuhan" (yang sekaligus membedakannya dengan Teologi Islam, Teologi Kristen, Teologi Hindu, dlsb.). Namun dalam banyak literatur, Filsafat Agama maupun Filsafat Ketuhanan dipahami sebagai bidang kajian yang sama. Pemilahan atau penyatuan bidang sangat tergantung dari "tradisi" pendidikan filsafat yang diikuti.

Theisme merupakan salah satu bagian dari kajian Teologi (harafiah: Theos = Tuhan, Logos = ilmu, pemikiran). Theisme sendiri merupakan suatu paham yang meyakini Tuhan itu Ada. Argumen-argumen yang dibangun untuk membuktikan bahwa Tuhan itu Ada, merupakan bagian dari upaya yang dilakukan oleh Teologi natural. Teologi natural merupakan sebuah usaha untuk memperoleh kesimpulankesimpulan yang bermakna tentang eksistensi Tuhan yang didasarkan hanya pada pikiran manusia saja. Teologi natural bersandar pada kemampuan-kemampuan kognitif manusia seperti: pengalaman, ingatan, instropeksi, penalaran deduktif, penalaran induktif, dan inferensi, untuk mendapatkan eksplanasi yang paling baik. Ini berbeda dengan Teologi perwahyuan (revealed theology) yang mendasarkan arumentasinya pada pernyataan-pernyataan yang dinyatakan telah difirmankan oleh Tuhan atau atas dasar kejadian-kejadian yang dianggap suatu ungkapan dari Tuhan (Davis, 1997: ix). Dengan demikian, per disiplin, Teologi natural termasuk kajian filsafat, walau dalam sejarah dan perkembangannya ia juga menjadi bagian dari Teologi perwahyuan. Yang dibicarakan dalam makalah kecil ini adalah Teologi natural.

Secara umum, bukti-bukti adanya Tuhan (theisticproofs, selanjutnya: TP) dipilah menjadi dua, yakni bukti a priori dan bukti a posteriori. TP a priori hanya terdiri dari satu macam, yakni argumentasi ontologis (the ontological argument), yakni argumentasi yang tidak didasarkan pada klaim klaim cmpiris tentang dunia, namun hanya melulu didasarkan pada gagasan-gagasan, konsep-konsep, atau definisidefinisi tertentu. Adapun TP a posteriori terdiri dari berbagai macam, yakni: the cosmological argumentyang berpegang pada kebenaran-kebenaran tertentu yang sudah pasti (tentang "gerak", "keterbatasan") dan adanya eksistensi ada (being) tertentu yang mampu menjelaskan fakta-fakta tersebut; design or teleological 
argument yang berpegang bahwa terdapat a divine designerorordereryang merancang dan mengatur tatanan dan rancangan sebagaimana yang dapat diamati di dunia; the moral argument bahwa terdapat suatu sumber ilahiah dari pengalaman moral manusia atau sumber ilahiah kebaikan yang tertinggi; dan the argument from religious experienceyang berpegang pada argumentasi bahwa keber-ada-an Tuhan paling baik dijelaskan atas dasar fakta pengalaman religius manusia (Davis, 1997: xi).

Di samping argumen "pokok" di atas, terdapat argumen-argumen lain yang juga tidak kalah menarik: the argument e consesu gentinum (argumentasi yang didasarkan atas fakta bahwa di mana-mana terdapat banyak 'orang beriman' terhadap Tuhan, dengan demikian Tuhan tentu Ada. Oleh: Cicero), the argument from morality (bahwa adanya moralitas kewajiban menuntut imbalan, yang karena belum tentu dapat dipenuhi pada saat hidup, tentu harus dipenuhi pada kehidupan setelah mati, dan oleh karenanya harus ada Tuhan untuk menjaminnya, oleh: Kant), the argument from aestheticsexperience (bahwa fakta adanya kesadaran estetis pada manusia - yang terbatas - tentu memiliki sumber pada sesuatu yang supra-human, dan itu adalah Tuhan), the epistemological argument (bahwa adanya kebenaran yang dapat dipahami manusia tentu bersumber pada Kebenaran Abadi, yakni Tuhan. Oleh: Agustinus), the argument from parapsycology (Extra-Sensory Perception, telepati, tafsir mimpi, penglihatan hantu, Near Death Experiences yang dihubungkan dengan eksistensi Tuhan (Hubbeling, 1987: 121-130).

Terlepas dari argumentasi apa pun untuk membuktikan bahwa Tuhan itu Ada, semua tergantung pada konsep atau pengertian: apa itu Tuhan! (Washburn, 1997: 27). Orang dapat saja tidak memasukkan persoalan tentang "apa itu Tuhan" sebagai persoalan yang harus dicari jawabnya sebelum mati. Pertama, mungkin, karena jawabannya sudah disediakan agama dan tinggal bertanya pada "para ahli", nya. Kedua, mungkin menganggap persoalan tersebut bukan persoalan "hidup-mati", artinya kita masih dapat "tidur", "bangun", "makan", "kuliah" (selain di fakultas filsafat, tentu), pacaran, merencanakan punya anak berapa - tanpa "hidup dengan persoalan tersebut!" Ketiga, mungkin orang takut pada "resiko" yang harus ditanggung bila mengkaji persoalan "Ada - tidak adanya Tuhan" secara kritis, radikal, dan rasional - karena apabila argumentasi-argumentasi tentang eksistensi Tuhan ditolak, maka konsekuensinya adalah sebuah perubahan hidup, terlepas menjadi atheis atau tidak!!!

Keberatan dan Sanggahan

Keberatan atau pun sanggahan rasional terhadap pernyataan bahwa Tuhan itu Ada, biasanya "dibangun" oleh sebuah paham yang dinamakan Atheisme. Dikatakan "dibangun" karena sekalipun dibawah tekanan agama dan tekanan sosial gagasan-gagasan atheistis sudah muncul sejak lama, dalam filsafat bahkan sejak Sokrates (yang clihukum mati karena mengajarkan pada generasi muda untuk tidak percaya pada dewa). Sejarah atheisme di Inggris memperlihatkan bahwa atheisme 
abad ke-20 justru berbasis pada atheisme militan dan atheisme akademis sebagaimana dirintis sebelumnya oleh Mill, dan dikembangkan oleh Moore dan Russell (Berman, 1990: 212-233). Mereka membangun argumentasi yang rigit yang kontrair dengan argumentasi theistis. Bahkan mereka membangun moralitas atheistis yang bersumber pada logika dan etika. Bahkan lebih dari sebelumnya, mereka berani "menantang" Tuhan secara terbuka. Pernyataan Mill memperlihatkan hal ini, yang bila diterjemahkan secara bebas berbunyi: "Apa pun kekuatan yang berada di atasku, satu hal yang tak akan dia tak ingin aku melakukannya: dia tak akan memerintahku untuk menyembahnya. Aku akan menyebutnya sebagai bukan sesuatu yang baik, bila misalnya aku melakukan itu pada maklukciptaanku; dan bila sesuatu itu mengirimkankukeneraka karena aku tidak menyembahnya, maka ke neraka aku akan pergi" (Mill, dalam: Berman, 1990: 236). Sesuatu yang mirip dilakukan oleh Ra'biah, walau dengan makna yang sebaliknya!

Tidak banyak yang dapat saya paparkan dalam tulisan yang pendek ini, yang dapat anda tuntaskan melalui kajian pustaka yang relevan. Namun yang terpenting adalah bagaimana harus bersikap sebagai orang yang bergumul dengan persoalan filosofis, se-"ringan" dan se-"berat" apa pun persoalan tersebut.

\section{PENUTUP}

Sebagai cendekia yang bergumul dengan persoalan-persoalan filsafat, setidaknya mulai detik ini, kita tidak perlu lagi bingung menjawab bila ditanya: Saudara kuliah filsafat itu mau hidup dengan apa? Jawabnya sudah jelas: hidup dengan pertanyaan!

Selamat bertanya!

Tjahyadi@filsafat.ugm.ac.id

\section{DAFTAR PUSTAKA}

Davis, Stepen T., 1997, God, Reason, \& Theistic Proofs, WM. B. Eerdmans Publishing Company, Michigan.

Graybosch, Anthony, \& Scoot, Gregory M., \& Garrison, Stephen, 1998, The Philosophy Student Writer's Manual, Prentice Hall, New Jersey.

Hubbeling, H.G., 1987, Principles of the Philosophy of Religion, Van Gorcum, Assen.

Windt, Peter Y., 1982, An Introduction to Philosophy: Ideas in conflict, West Publishing Company, New York.

Washburn, Phil, 1997, Philosophical Dilemmas, Building a worldview, Oxford University Press, Oxford. 